\title{
Whole Blood, Fixed Ratio, or Goal-Directed Blood Component Therapy for the Initial Resuscitation of Severely Hemorrhaging Trauma Patients: A Narrative Review
}

\author{
Mark Walsh ${ }^{1,2}$, Ernest E. Moore ${ }^{3,4}$, Hunter B. Moore ${ }^{4}$, Scott Thomas ${ }^{5}$, Hau C. Kwaan ${ }^{6}$, Jacob Speybroeck ${ }^{1}$, \\ Mathew Marsee ${ }^{1}$, Connor M. Bunch ${ }^{1}{ }^{(0}$, John Stillson ${ }^{1}{ }^{\circledR}$, Anthony V. Thomas ${ }^{1}$, Annie Grisoli ${ }^{1}{ }^{\circledR}$, John Aversa ${ }^{7}$, \\ Daniel Fulkerson ${ }^{8}$, Stefani Vande Lune ${ }^{9}$, Lucas Sjeklocha ${ }^{10}$ and Quincy K. Tran ${ }^{10, *(1)}$
}

check for

updates

Citation: Walsh, M.; Moore, E.E. Moore, H.B.; Thomas, S.; Kwaan, H.C.; Speybroeck, J.; Marsee, M.; Bunch, C.M.; Stillson, J.; Thomas, A.V.; et al. Whole Blood, Fixed Ratio, or Goal-Directed Blood Component Therapy for the Initial Resuscitation of Severely Hemorrhaging Trauma Patients: A Narrative Review. J. Clin. Med. 2021, 10, 320. https://doi.org/ $10.3390 /$ jcm10020320

Received: 10 November 2020 Accepted: 15 January 2021 Published: 17 January 2021

Publisher's Note: MDPI stays neutral with regard to jurisdictional clai$\mathrm{ms}$ in published maps and institutional affiliations.

Copyright: (C) 2021 by the authors. Licensee MDPI, Basel, Switzerland. This article is an open access article distributed under the terms and conditions of the Creative Commons Attribution (CC BY) license (https:// creativecommons.org/licenses/by/ $4.0 /)$.
1 Notre Dame Campus, Indiana University School of Medicine, South Bend, IN 46617, USA; markwalshmd@gmail.com (M.W.); speybroeckjacob@gmail.com (J.S.); mkmarsee@gmail.com (M.M.); cmbunch@iu.edu (C.M.B.); jstills@iu.edu (J.S.); 33thomasa@gmail.com (A.V.T.); agrisoli@iu.edu (A.G.)

2 Departments of Emergency \& Internal Medicine, Saint Joseph Regional Medical Center, Mishawaka, IN 46545, USA

3 Ernest E. Moore Shock Trauma Center, Denver Health, Denver, CO 80204, USA; Ernest.moore@dhha.org

4 Department of Surgery, University of Colorado Health Science Center, Denver, CO 80204, USA; hunter.moore@ucdenver.edu

5 Department of Trauma Surgery, Memorial Leighton Trauma Center, Beacon Health System, South Bend, IN 46601, USA; SThomas@beaconhealthsystem.org

6 Division of Hematology and Oncology, Department of Medicine, Northwestern University Feinberg School of Medicine, Chicago, IL 60611, USA; h-kwaan@northwestern.edu

7 Department of Surgery, Indiana University School of Medicine, Indianapolis, IN 46202, USA; javersa@iupui.edu

8 Department of Neurosurgery, Beacon Medical Group, South Bend, IN 46601, USA; dhfulkerson@beaconhealthsystem.org

9 Emergency Medicine Department, Navy Medicine Readiness and Training Command, Portsmouth, VA 23708, USA; stefani.vandelune@gmail.com

10 The R Adams Cowley Shock Trauma Center, University of Maryland School of Medicine, Baltimore, MD 21201, USA; lsjeklocha@som.umaryland.edu

* Correspondence: qtran@som.umaryland.edu

\begin{abstract}
This narrative review explores the pathophysiology, geographic variation, and historical developments underlying the selection of fixed ratio versus whole blood resuscitation for hemorrhaging trauma patients. We also detail a physiologically driven and goal-directed alternative to fixed ratio and whole blood, whereby viscoelastic testing guides the administration of blood components and factor concentrates to the severely bleeding trauma patient. The major studies of each resuscitation method are highlighted, and upcoming comparative trials are detailed.
\end{abstract}

Keywords: blood transfusion; blood component transfusion; exsanguination; fibrinogen; hemostatics; thromboelastography

\section{Introduction: Rationale for the Adoption of Whole Blood and Fixed Ratio Resuscitation}

1.1. History of the United States' Swift Adoption of Cold-Stored Whole Blood for Civilian Urban Trauma Resuscitation

Since 2016, many large United States academic centers have embarked upon an ambitious program to offer whole blood (WB) in the civilian and urban prehospital environment for severely hemorrhaging patients. This process required variances from the American Association of Blood Banks recommendations [1,2]. In austere and rural environments where no blood banking or testing is available, cold-stored WB (CSWB) may be the best empiric agent for prehospital resuscitation of the severely bleeding patient. Prehospital fresh frozen 
plasma is commonly available. However, recent studies demonstrate that platelet dysfunction and fibrinogen deficiency are of paramount importance in early trauma-induced coagulopathy (TIC) [1-4]. Therefore, some urban academic trauma systems with short transport times have been early adopters of CSWB. Many of these academic centers who advocate for trauma resuscitation with $\mathrm{WB}$ are led by trauma specialists with military backgrounds [1,2]. In turn, there has been a significant drive to provide CSWB not only in the rural civilian environment-where its use is beneficial given transport times and resource limitations-but also to the urban nonacademic environment with short transport times [1-10]. Without access to similar robust academic and/or military ties, these nonacademic trauma centers may not have the resources to offer WB as easily as their academic and military counterparts. Therefore, the mechanistic rationale for the provision of CSWB in the civilian and urban environment requires historical evaluation prior to its widespread adoption.

\subsection{PROPPR Trial as Mechanistic Rationale for Justification of CSWB}

WB resuscitation garnered practical support by the demonstration that a fixed ratio of equal parts plasma, platelets (PLTs), and packed red blood cells (PRBCs) improves mortality. The 2015 Pragmatic, Randomized Optimal Platelet and Plasma Ratios (PROPPR) trial established use of balanced blood transfusion. This study of 680 patients from 12 centers suggested that a fixed ratio of 1:1:1 (plasma/PLTs/PRBC) provided a benefit to mortality caused by exsanguination at $24 \mathrm{~h}$ but no overall mortality benefit when compared to a ratio of 1:1:2 [11]. The PROPPR trial has received significant scrutiny because of the lack of benefit in overall $24 \mathrm{~h}$ mortality. The trial has also received criticism for inconsistencies and confounding variables. PLTs were not provided to the 1:1:2 group until after 6 units of PRBCs were administered. Moreover, cryoprecipitate or fibrinogen were not components of either regimen. Plasma was often administered well after the initial resuscitation period but within the first $24 \mathrm{~h}$. This phenomenon was termed "catch up" and implied that these patients did not receive equal components during the critical first few hours of resuscitation. Therefore, patients never truly received a fixed 1:1:1 ratio during the initial resuscitation period. Finally, patients whose cause of death was exsanguination included those who also had traumatic brain injury (TBI), which confounded the cause of death [11-14]. A followup systematic review of 16 randomized controlled trials (RCTs) stated similar concerns regarding the recommendations of the PROPPR trial. Given the diversity of patients with blunt or penetrating trauma and with or without TBI, additional studies are required to determine the mortality benefit of 1:1:1 vs. 1:1:2 fixed ratios $[12,15,16]$. Due to the concerns about the validity of the PROPPR trial, which set the standard for the fixed 1:1:1 practice, we review the reasons for the widespread adoption of CSWB in the United States for civilian urban trauma.

\subsection{Historical Justification for CSWB in Civilian Urban Trauma}

Few retrospective studies and only one RCT compared WB versus fixed ratio for resuscitation in the urban civilian population (Table 1). The first study comparing WB versus standard blood component therapy (BCT) for civilian resuscitation was published in 2009. Since then, the paucity of literature mostly constitutes editorials or papers on the feasibility of applying far forward combat WB use to the civilian arena. A total of 1382 civilian patients form the foundation of WB's widespread adoption in the United States' urban areas [1-6,17-38]. The most recent small studies revealed an equivocal mortality benefit from overuse of WB because "it was easier and faster in a chaotic and busy trauma bay" [29]. Moreover, it was recently noted that "WB is not effective at treating traumatic hemorrhage in resuscitation as compared with component therapy" [33]. Broad introduction of CSWB in the absence of high-quality trials will likely lead to further heterogeneity of guidelines among hospital systems and education programs. Three RCTs, discussed later, are currently underway and the results will not be reported for over a year. Given the scant literature justifying CSWB in the prehospital and urban environment for 
trauma, and the concerns regarding the PROPPR trial, consideration of viscoelastic test (VET)-guided trauma resuscitation is warranted.

Table 1. Studies of WB in the Civilian Population.

\begin{tabular}{|c|c|c|c|c|}
\hline Study & $\begin{array}{l}\text { Number of Patients } \\
\text { Receiving WB }\end{array}$ & Study Design & Description & Results \\
\hline Cotton et al. [28] & 55 & $\mathrm{RCT}$ & $\begin{array}{c}\text { Single-center, RCT } \\
\text { comparing modified WB } \\
\text { and component therapy }\end{array}$ & $\begin{array}{l}\text { No difference in } 30 \text { day } \\
\text { mortality. Possible } \\
\text { transfusion benefit in } \\
\text { TBI. }\end{array}$ \\
\hline Williams et al. [33] & 198 & $\begin{array}{l}\text { Comparative clinical } \\
\text { prospective therapeutic } \\
\text { study }\end{array}$ & $\begin{array}{c}\text { Comparison of LTOWB } \\
\text { versus BCT in prehospital } \\
\text { and ED setting for trauma } \\
\text { patients }\end{array}$ & $\begin{array}{l}\text { LTOWB received less } \\
\text { post-ED blood products } \\
\text { with equivocally } \\
\text { mortality benefit. }\end{array}$ \\
\hline Hanna et al. [36] & 280 & $\begin{array}{l}\text { Retrospective cohort } \\
\text { analysis }\end{array}$ & $\begin{array}{l}\text { Analysis of 2015-2016 ACS } \\
\text { TQIP database comparing } \\
\text { patients in hemorrhagic } \\
\text { shock and given at least } \\
\text { one unit of PRBCs or WB } \\
\text { (note this likely includes } \\
\text { patients from other studies) }\end{array}$ & $\begin{array}{l}\text { WB associated with } \\
\text { improved } 24 \mathrm{~h} \\
\text { mortality overall and } \\
\text { improved in-hospital } \\
\text { mortality in subgroups } \\
\text { with penetrating } \\
\text { mechanism and those } \\
\text { without severe head } \\
\text { injury. }\end{array}$ \\
\hline $\begin{array}{l}\text { Ho and Leonard } \\
\text { [31] }\end{array}$ & 77 & $\begin{array}{l}\text { Retrospective cohort } \\
\text { study }\end{array}$ & $\begin{array}{l}\text { Unrefrigerated young WB } \\
\text { transfusion for patients } \\
\text { requiring massive } \\
\text { transfusion in a civilian } \\
\text { setting }\end{array}$ & $\begin{array}{l}\text { No benefit (overall } \\
\text { survival and } \\
\text { transfusion were } \\
\text { equivalent) }\end{array}$ \\
\hline Leeper et al. [38] & 28 & $\begin{array}{l}\text { Propensity matched } \\
\text { cohort }\end{array}$ & $\begin{array}{l}\text { Propensity matched cohort } \\
\text { of children over } 1 \text { year }\end{array}$ & $\begin{array}{c}\text { No difference in } \\
\text { mortality. Improved } \\
\text { indices of shock and } \\
\text { coagulopathy. }\end{array}$ \\
\hline Seheult et al. [22] & 172 & $\begin{array}{c}\text { Retrospective } \\
\text { case-control analysis }\end{array}$ & $\begin{array}{l}\text { Safety analysis of LTOWB } \\
\text { patients by blood group }\end{array}$ & $\begin{array}{l}\text { No mortality difference, } \\
\text { similar clinical } \\
\text { outcomes across } \\
\text { groups, no increased } \\
\text { hemolysis noted at } 24 \mathrm{~h} \\
\text { in nongroup O patients. }\end{array}$ \\
\hline Fadeyi et al. [35] & 167 & Retrospective cohort & $\begin{array}{c}\text { Comparison trauma } \\
\text { patient receiving LTOWB } \\
\text { with leuko-reduced } \\
\text { LTOWB }\end{array}$ & $\begin{array}{c}\text { Nonstatistically } \\
\text { significant } 6 \% \\
\text { increased mortality in } \\
\text { leuko-reduced LTOWB } \\
\quad(p=0.185) .\end{array}$ \\
\hline Hazelton et al. [30] & 107 & $\begin{array}{l}\text { Dual-center case-match } \\
\text { study }\end{array}$ & $\begin{array}{c}\text { Matching analysis for } \\
\text { patients who received } \\
\text { CSWB vs. BCT for } \\
\text { hemodynamic parameters, } \\
\text { hemoglobin and } \\
\text { hematocrit at } 24 \text { h, trauma } \\
\text { bay mortality, and } 30 \text { day } \\
\text { mortality }\end{array}$ & $\begin{array}{l}\text { CSWB associated with } \\
\text { improved trauma bay } \\
\text { survival and higher } \\
\text { mean hemoglobin } \\
\text { value at } 24 \mathrm{~h} \text {. } \\
\text { No difference in the } \\
\text { amount of blood } \\
\text { products transfused at } \\
4 \text { and } 24 \mathrm{~h} \text { periods.No } \\
\text { difference in } 30 \text { day } \\
\text { mortality between the } \\
\text { two groups. }\end{array}$ \\
\hline
\end{tabular}


Table 1. Cont.

\begin{tabular}{|c|c|c|c|c|}
\hline Study & $\begin{array}{l}\text { Number of Patients } \\
\text { Receiving WB }\end{array}$ & Study Design & Description & Results \\
\hline Shea et al. [37] & 44 & $\begin{array}{l}\text { Prospective } \\
\text { observational }\end{array}$ & $\begin{array}{c}\text { Before-and-after } \\
\text { comparison of trauma } \\
\text { patient requiring activation } \\
\text { of massive transfusion } \\
\text { before and after } \\
\text { implementation of LTOWB } \\
\text { MTP (up to } 8 \text { LTOWB unit) }\end{array}$ & $\begin{array}{l}\text { No difference of absolute } \\
\text { mortality between } \\
\text { groups. Post-hoc } \\
\text { multivariate regression } \\
\text { showed improved } \\
\text { adjusted mortality in } \\
\text { LTOWB group. Authors } \\
\text { argue for effect } \\
\text { mediation based on } \\
\text { ROTEM parameters. }\end{array}$ \\
\hline $\begin{array}{l}\text { Gallaher et al. } \\
\text { [29] }\end{array}$ & 42 & $\begin{array}{l}\text { Retrospective } \\
\text { observational }\end{array}$ & $\begin{array}{c}\text { Before-and-after } \\
\text { comparison of mortality in } \\
\text { trauma patients receiving } \\
\text { blood products during } \\
\text { implementation of LTOWB } \\
\text { program }\end{array}$ & $\begin{array}{l}\text { LTOWB did not alter } \\
30 \text { day mortality, } \\
\text { nonstatistically } \\
\text { significant increase in } \\
\text { total blood products, and } \\
\text { no difference in lab } \\
\text { values at } 48 \mathrm{~h} .\end{array}$ \\
\hline Zielinski et al. [2] & $\begin{array}{c}24 \text { Mayo } \\
22 \text { Pittsburgh } 73 \text { Royal } \\
\text { Caribbean }\end{array}$ & $\begin{array}{l}\text { Retrospective } \\
\text { observational }\end{array}$ & $\begin{array}{c}\text { Describes the THOR } \\
\text { network prehospital WB } \\
\text { programs including Mayo } \\
\text { Clinic and Allegheny } \\
\text { General Hospital and } \\
\text { WFWB transfusion on } \\
\text { Royal Caribbean cruise }\end{array}$ & $\begin{array}{c}\text { Observation only. } \\
\text { Overall mortality in } \\
\text { patients who received } \\
\text { WB } 31 \% .\end{array}$ \\
\hline Seheult et al. [25] & 44 & Observational study & $\begin{array}{l}\text { Hemolysis markers in } \\
\text { group O and nongroup O } \\
\text { recipients of platelet } \\
\text { replete, uncrossmatched } \\
\text { CSWB }\end{array}$ & $\begin{array}{c}\text { No difference in } \\
\text { hemolysis markers across } \\
\text { groups. }\end{array}$ \\
\hline Zhu et al. [19] & 30 & $\begin{array}{l}\text { Retrospective } \\
\text { observational }\end{array}$ & $\begin{array}{l}\text { Descriptive study of } \\
\text { prehospital WB transfusion } \\
\text { implementation which } \\
\text { included transfusion of } 25 \\
\text { adults and } 5 \text { pediatric } \\
\text { patients }\end{array}$ & $\begin{array}{l}\text { Observational. } \\
\text { Mortality in adult: } 36 \% \text {; } \\
\text { mean ISS: } 29 . \text { Mortality } \\
\text { in pediatric: } 20 \% \text {; mean } \\
\text { ISS: } 29 . \\
\text { Mean transport time, } \\
37 \text { min. }\end{array}$ \\
\hline Leeper et al. [20] & 18 & $\begin{array}{l}\text { Retrospective } \\
\text { observational }\end{array}$ & $\begin{array}{l}\text { Pediatric uncrossmatched } \\
\text { LTOWB transfusion for } \\
\text { hemorrhagic shock }\end{array}$ & ISS: 34. Mortality $44 \%$. \\
\hline $\begin{array}{l}\text { Condron et al. } \\
\text { [27] }\end{array}$ & 1 & Case report & $\begin{array}{l}\text { Case report of massive } \\
\text { transfusion using } 38 \text { units } \\
\text { of LTOWB in addition to } \\
\text { MTP with blood } \\
\text { components }\end{array}$ & $\mathrm{N} / \mathrm{A}$ \\
\hline
\end{tabular}

Abbreviations: ACS, American College of Surgeons; BCT, blood component therapy; CSWB, cold-stored whole blood; ED, emergency department; ISS, injury severity score; LTOWB, low-titer group O whole blood; MTP, massive transfusion protocol; PRBCs, packed red blood cells; RCT, randomized controlled trial; ROTEM, rotational thromboelastometry; TBI, traumatic brain injury; THOR, Trauma Hemostasis and Oxygenation Research; TQIP, Trauma Quality Improvement Program; WB, whole blood; WFWB, warm fresh whole blood.

\section{VET-Guided Goal-Directed Resuscitation}

The rationale of CSWB and fixed ratios is based on the principle that the patient should be "given what they have lost" [39]. There are significant temporal changes within the complex spectrum of TIC within the first hours of resuscitation [40]. The complex pathophysiology of TIC often persists after the simple administration of fixed ratios or WB, and 
TIC remains a leading cause of mortality after resuscitation. TIC phenotypes, an intricate web of hemostatic and immunologic aberrancies, depend on factors such as penetrating versus blunt trauma, the presence of TBI, the time from injury to resuscitation, the genetic hematologic makeup of the patient, and the methods of resuscitation. The administration of either fixed ratios or WB does not represent a precision-based therapeutic approach to the individual patient's hemostatic derangements in TIC, especially when guided only by common coagulations tests such as the prothrombin time, international normalized ratio, activated partial thromboplastin time, PLT count, and fibrinogen. As a result, there has been advocacy for administration of BCT under the guidance of the VETs, including thromboelastography (TEG) and rotational thromboelastometry (ROTEM) [41-56]. This strategy of VET-guided goal-directed BCT (GD BCT) can be considered a better alternative for individualized resuscitation of the hemorrhaging trauma patient.

\subsection{History of VET and Trauma Resuscitation}

In 1997, the first case series of 67 trauma patients whose BCT was guided by TEG was published in the United States [57]. Since then, numerous papers in worldwide journals have detailed how TEG/ROTEM provides more efficient resuscitation of severe bleeding in not only trauma, but also surgical anesthesia and obstetrics [42,58-60]. However, the adoption of the TEG/ROTEM in the United States has remained stagnant. In 2016, it was discovered that only $9 \%$ of institutions used VET-guided BCT for patients who required large volume resuscitation [61,62]. Meanwhile, our European colleagues have adopted early and repeated VET-guided BCT as the bedrock of modern trauma resuscitation. Since the beginning of the century, European guidelines and their iterations have recommended VET-guided BCT for initial and ongoing resuscitation of the severely bleeding trauma patient [63-65]. Despite this significant history in Europe, VET-guided BCT has failed to gain acceptance in the United States where continued emphasis on common coagulations tests guide therapy. This may be explained in part by the inherent bias of blood bankers and hematologists who often lack familiarity with TEG/ROTEM due to institutional variability caused often by pipetting inconsistencies $[66,67]$. Standardization of VETs is being addressed with controlled cartridge systems, such as the TEG6S and ROTEM Sigma. These enable easier implementation of rapid test variants of VET assays and decreased time to potentially actionable information [68-71].

Initial trauma resuscitation in the United States may be led by either a trauma surgeon and anesthesiologist, or an emergency physician. There has been a recent push in the United States to approach trauma care with more attention to the pathophysiology of TIC. Thus, it is vital that acute care trauma surgeons and critical care surgeons are provided the educational impetus to advance the use of the VETs seamlessly throughout the hospital. Whether in Europe or the United States, a seamless transitioning of TIC prevention and management—guided by TEG/ROTEM-has resulted in a more physiologic replenishment of blood products in the trauma patient [68-70,72,73].

Since 2012, Germany has undergone concerted educational and institutional efforts to use VETs to guide trauma resuscitation in a more physiologic manner. At the beginning of the century, the multicenter trauma registry of the German Society for Trauma analyzed ratios of plasma, PRBCs, and PLTs and administration of coagulation factor concentrates (CFCs) in adult trauma. As a result, a significant reduction in crystalloid use and a higher ratio of plasma and PLTs to PRBC use, as well as an increase in CFCs, were noted to improve mortality in the studied time frame. Most recently, the findings of the German study group have advanced many areas of VET-guided BCT and hemostatic adjunct therapy with 4 -factor prothrombin complex concentrate (PCC) and soluble fibrinogen [47,74].

A Copenhagen group used a hybrid approach of an initial 1:1:1 fixed ratio followed by TEG-guided GD BCT with factor concentrates. This landmark study published in 2010 establishes the "Copenhagen Concept", which has become a standard for the treatment of hemorrhaging trauma patients [54,75]. Likewise, an Italian group using ROTEM-guided therapy has demonstrated a similar protocol wherein a preemptive dose of $2 \mathrm{~g}$ fibrinogen 
concentrate is administered for trauma patients in hemorrhagic shock. The Italian group demonstrated reduced blood product consumption, decreased overall cost, and improved early and 28 day mortality [76].

\subsection{History of VET Goal-Directed Therapy with Coagulation Factor Concentrate}

Personalized VET-guided direction of BCT possesses theoretical advantages over the $\mathrm{WB}$ and ratio-driven methods. Despite the increasing availability of rapidly obtainable VET results, which allow for the targeted supplementation of procoagulants, consensus among physicians regarding the use of factor concentrates is lacking, particularly in the United States. Prospective studies and RCTs comparing GD BCT with and without CFCs are necessary

Not all blood components are depleted equally in hemorrhage. Resuscitation itself causes the dilution of the coagulation process and factors. There has been renewed interest for the use of VET-guided fibrinogen administration in Europe and the United States. Fibrinogen is the precursor for clot formation and its level determines the clot stability early in resuscitation. Early prehospital and emergency department fibrinogen for preventing the progression of TIC has been a significant area of recent study. Attention has also been brought to early hospital use of PLT therapy in order to enhance the stability of the fibrin/PLT plug as studies have shown that higher ratios of PLTs provided early to patients with surgical and traumatic bleeding are associated with increased survival [77-84].

European studies reveal that cryoprecipitate replacement for fibrinogen levels greater than $1-5 \mathrm{~g} / \mathrm{L}$ was feasible in patients who required massive transfusion (MT). Studies have demonstrated the feasibility of providing fibrinogen concentrate to severely bleeding trauma patients. The Fibrinogen in the initial Resuscitation of Severe Trauma (FiiRST), REversal of Trauma-Induced Coagulopathy (RETIC), and Early-Fibrinogen In Trauma 1 (E-FIT1) studies, as well as the European prehospital Fibrinogen in Trauma-Induced Coagulopathy (FinTIC) trial, have demonstrated that soluble fibrinogen given early during trauma resuscitation may result in significant clinical benefit. The RETIC study used plasma in the control arm to treat early TIC and compared it to soluble fibrinogen in patients in whom ROTEM indicated a fibrinogen deficiency. The study was terminated early because a significant number in the plasma group required rescue therapy and MT compared to the CFC group. Soluble fibrinogen is costly while cryoprecipitate is less expensive and more readily available. The CRYOSTAT1 and two trials are designed to study the efficacy of cryoprecipitate for the maintenance of resuscitation for fibrinogen levels greater than $1.8 \mathrm{~g} / \mathrm{L}$. These trials advocate for the early administration of cryoprecipitate in the prevention and treatment of early TIC because of the early fibrinogen derangement as a cause of incipient TIC. Recent studies indicate that timely soluble fibrinogen concentrate administration is possible in the prehospital and urban hospital environment, with ROTEM evidence of increased clot stability. Future studies have been proposed to provide soluble fibrinogen and 4-factor PCC in the prehospital and hospital civilian urban setting as an alternative to fixed ratio or WB resuscitation [85-96]. Since 2017 in Australia, the Fibrinogen Early In Severe Trauma study (FEISTY) is a RCT attempting to address the validity of soluble fibrinogen for early resuscitation of severely bleeding trauma patients [97].

With precision-based medicine guided by VETs, the hemorrhaging trauma patient's resuscitation is provided by a finely-tuned menu to address their individual hemostatic deficits. TEG/ROTEM-guided therapies represent an area of promise mastered by more than a few European centers, but lags in the United States where CFCs are not yet approved for trauma resuscitation [98].

\subsection{Recent Challenge to VET-Guided Trauma Resuscitation: The iTACTIC Trial}

A recent RCT has challenged the value of VET-guided BCT and CFC in severely bleeding patients. The implementing Treatment Algorithms for the Correction of TraumaInduced Coagulopathy (iTACTIC) trial compared VETs to the standard coagulation tests in bleeding trauma patients. This trial demonstrated no statistical evidence that the use of 
VETs versus standard therapy guided by standard coagulation tests improved 28 day mortality. However, similar confounding factors were also found with the PROPPR trial [99]. Despite the high injury severity scores, a relatively small percentage of either group received MT within $24 \mathrm{~h}$. This is also reflected by the low incidence of TIC in both groups. Like the PROPPR trial, no proportion of patients were identified with significant surgical bleeding. Moreover, there was a confluence of those patients with TBI and hemorrhagic death, rendering any causal link of death to hemorrhage problematic. While some of the centers in the iTACTIC trial had been performing TEG and ROTEM at a clinical level for many years, other centers began their practical experience with VETs at the beginning of the study. The authors of the iTACTIC study note the challenges in attempted performance homogeneity among the seven centers. This raises significant concern for the validity of the results, as there is a steep learning curve in the adoption of VETs to guide BCT and CFCs for severely bleeding patients. Additionally, the authors of the trial do not comment on the percentage of centers which used either ROTEM or TEG devices to guide BCT. They state: "The [VET] used at each study site was determined by existing familiarity with a specific device appliance and to ensure a balanced use of the devices across the study" [99]. This is of importance due to the heterogeneity of thresholds for administering BCT $[100,101]$. Finally, a problem consistent with many studies regarding the treatment and diagnosis of patients with severe bleeding and trauma is the definition of MT as 10 units PRBCs in $24 \mathrm{~h}$. This may explain the low incidence of TIC in the iTACTIC study considering that the most effective time for intervention to reverse the pathophysiology of TIC is the first few hours after injury. Only $28 \%$ in the standard coagulation tests group and $26 \%$ in the VET group had received MT at $24 \mathrm{~h}$ [99]. This traditional MT definition restricts the potential study sample to a less acute group of patients, excludes patients who die early, and excludes those who may have benefitted from early use of VET-guided resuscitation [102]. These issues indicate that the population studied may not have been sick enough to benefit from VET-guided trauma resuscitation [99]. More recent data suggest that $>4$ units PRBCs in the first hour is a more meaningful definition of MT [103].

\section{Geographic Variations}

Comparison of the United States and European trauma data is confounded by the relatively high incidence of penetrating injury in the United States. The United States' emphasis on WB may stem from this high incidence of penetrating injury as an early cause of potentially preventable hemorrhage (PPH), serving as an impetus to provide WB in the civilian urban environment. It has been reported that $34.5 \%$ of patients died from $\mathrm{PPH}$ in the prehospital setting or within an hour of hospitalization for all forms of trauma. Hence, the use of WB in the early prehospital and emergency department environment has been viewed as a more effective method for prehospital resuscitation to decrease deaths from PPH [104].

The incidence of penetrating injury varies among developed countries. In major United States trauma centers in large metropolitan areas, the incidence may be as high as $45 \%$ of all injuries, whereas in Europe the percentage of penetrating injuries is much lower $(0.2-5 \%$ in Switzerland, the Netherlands, and Germany) $[105,106]$.

Resuscitation of these penetrating injuries also depends on immediate surgical control of hemostasis. Therefore, this population may not be directly comparable to the European population, where motor vehicle accidents with a high incidence of TBI confer different methodologies of resuscitation. Nevertheless, it is notable that the country with the highest use of VETs also has the least use of prehospital blood products administered in a fixed ratio. Germany, with its centralized system and relatively short transport times, uses prehospital blood products in 6\% of trauma centers. Comparatively in France, the rate is $89 \%$ [16]. It is not surprising that the only European RCT for using CSWB in the civilian urban population is in France, where the time spent in the field on resuscitation efforts is longer than the "scoop and run" strategy used in the United States, where physicians are not onboard ambulances [107]. 
The equivocal success of prehospital administration of blood products in the civilian urban environment has been inconsistently replicated in other studies. A recent review of the European literature suggests that prehospital blood transfusion with or without PRBCs resulted in equivocal reduction of $24 \mathrm{~h}$ mortality $[15,85,108]$. The authors caution that "based on mainly poor-quality evidence, no hard conclusion can be drawn about a possible survival benefit for hemorrhagic trauma patients receiving prehospital blood transfusion. Overall, prehospital blood transfusion is safe, but the results of currently ongoing RCTs await to demonstrate a survival benefit." [15]. However, the European Society of Anesthesiology recently reported that $48 \%$ of responders to an online survey had access to PRBCs, $22 \%$ to fresh plasma, and 14\% to lyophilized plasma [16]. It is clear that there were significant dissimilarities in practice among European countries with no consensus regarding the benefit of prehospital blood products [16]. Hence, there is a tremendous need for continued investigation in RCTs.

On the other hand, European trauma specialists have provided substantial literature confirming the use of VETs to guide resuscitation in the last two decades. An expanding emphasis for use of VET-guided BCT in trauma resuscitation has developed throughout Europe and the United States [40,42,44,46,47,54,55,90,94,109-121].

The most significant difference between Europe and the United States concerns the frequent use of VET-guided administration of PCC, soluble fibrinogen, PRBCs, and PLTs. The European reliance on VET-guided resuscitation and CFC therapy is significant; 2019 guidelines no longer recommend the use of plasma for the treatment of hypofibrinogenemia.

The European guidelines are significant in that fibrinogen and PLT dysfunction are addressed among the first abnormalities in patients with TIC. The volume of plasma required to correct this fibrin deficiency, documented by ROTEM, would result in unnecessary dilution and potential worsening of the coagulopathy. The RETIC study demonstrated the superiority of CFC when compared to plasma [78-84]. Highly specialized trauma centers in Switzerland, Austria, and Germany have published studies demonstrating mortality improvement for patients with severe trauma who are treated in a goal-directed fashion with CFCs and minimal crystalloid [78,85,87,94,111,118,122,123].

VET-guided GD BCT has now been used in the United States and Europe with increasing frequency and earlier in the phases of care. From our literature search, there was no evidence of VET use in the prehospital environment. VETs are not useful in the prehospital setting because vibrations in a moving ambulance result in an inaccurate tracing.

\section{Future Direction-RCTs in Progress}

There are three ongoing trials for early trauma resuscitation with WB for severely bleeding patients, the PPOWER trial, the STORHM trial, and the SWAT trial.

\subsection{PPOWER}

The Pragmatic, Prehospital, Type O, Whole Blood Early Resuscitation (PPOWER) trial, a single-center, 3 year, prospective randomized pilot trial of type O low-titer, leukocytereduced (LTLR) WB, is in progress at Pittsburgh, United States. This trial is based in the helicopter prehospital setting followed by LTLR WB in the hospital. Four helicopter centers are provided with WB for this study. Patients will receive 6 units of WB upon entry into the study. Of note, previous protocols called for 2 units of WB, then transitioned to TEG-guided GD BCT. This study provides a higher number of WB units followed by TEG-guided resuscitation, rendering this a hybrid study combining the use of WB, fixed ratios, and TEG-guided GD BCT. The hypothesis of this study is that WB will provide better outcomes for the early resuscitation of trauma patients, particularly when combined with TEG-guided BCT. Proposed completion is by late 2021 [124]. 


\subsection{STORHM}

A French study (Sang Total pour la Reanimation des Hemorragies Massives, STORHM) is still in the planning stage as a noninferiority study to compare LTLR WB to a 1:1:1 fixed ratio for the severely hemorrhaging trauma patient. Like the PPOWER study, the endpoint will be mortality, but TEG parameters will also be analyzed. Other endpoints are to include lactate clearance and the presence of multiorgan failure at $24 \mathrm{~h}$. It is anticipated that this trial, which began in late 2019, will recruit 200 patients from six trauma centers [125].

\subsection{SWAT}

Finally, the Linking Investigations in Trauma and Emergency Services networka consortium of trauma centers that conduct prospective, multicenter, injury care, and outcomes research — has sponsored the Shock, Whole Blood, and Assessment of TBI (SWAT) trial to compare $\mathrm{WB}$ and standard $\mathrm{BCT}$. This trial is a 4 year, multicenter, prospective, observational cohort study that will analyze early WB resuscitation compared to standard $\mathrm{BCT}$ resuscitation for trauma patients with severe hemorrhagic shock, with and without TBI. Completion is scheduled for February 2022 [9].

\section{Conclusion}

Historical, geographical, and mechanistic components influence the selection of fixed ratio blood component and WB resuscitation for severely bleeding trauma patients. Because of an institutional reliance in the United States, based on the paradigm of far forward combat resuscitation where WB is commonly used, a rapid implementation of WB in the civilian urban resuscitation has occurred. In much of Europe, however, with a long tradition of VET-guided trauma resuscitation, fixed ratio resuscitation is less commonly used and WB is only used in the initial stages of investigation. Until recently, few academic trauma centers in the United States have used VETs to guide trauma resuscitation, rather adhering to fixed ratios or CSWB. The advantages and disadvantages of the three resuscitation methods are summarized in Table 2.

Table 2. Advantages and disadvantages of whole blood vs. fixed ratio vs. VET-guided BCT.

\begin{tabular}{|c|c|c|}
\hline & Advantages & Disadvantages \\
\hline Whole blood & $\begin{array}{ll}\text { - } & \text { Simple protocols and uniform dosing } \\
\text { - } & \text { Easy to administer in prehospital and hospital } \\
\text { setting } \\
\text { - } \\
\text { Provides all blood components; avoids } \\
\text { hemodilution }\end{array}$ & $\begin{array}{ll}\text { - } & \text { Not physiologically driven } \\
\text { - } & \text { Few RCTs } \\
\text { - } & \text { Unnecessary blood components may be given- } \\
\text { Products currently not universally available; } \\
\text { shorter shelf life } \\
\text { - } \quad \text { Requires AABB variances and additional cost }\end{array}$ \\
\hline Fixed ratio & $\begin{array}{ll}\text { - } & \text { Simple protocols and uniform dosing } \\
\text { - } & \text { Easy to administer in prehospital and hospital } \\
\text { setting } & \\
\text { - } & \text { More RCTs, but questionable validity } \\
\text { - } & \text { regarding 1:1:1 vs. 1:1:2 } \\
\text { Blood components readily available }\end{array}$ & $\begin{array}{ll}\text { - } & \text { Not physiologically driven } \\
\text { - } & \text { Unnecessary blood components may be given } \\
\text { - } & \text { Does not replenish fibrinogen effectively in } \\
\text { early stages }\end{array}$ \\
\hline VET-guided BCT & $\begin{array}{ll}\text { - } & \text { Provides early physiologically driven } \\
\text { resuscitation } \\
\text { - } \quad \text { Limits blood product waste } \\
\text { - } \quad \text { Blood components readily available }\end{array}$ & $\begin{array}{ll}\text { - } & \text { Protocols not straight forward; accuracy } \\
\text { operator dependent; steep learning curve } \\
\text { - } \quad \text { Cannot be used in prehospital setting } \\
\text { - } \quad \text { Few RCTs }\end{array}$ \\
\hline
\end{tabular}

Abbreviations: AABB, American Association of Blood Banks; BCT, blood component therapy; RCT, randomized control trial; VET, viscoelastic test $[1-11,14,40,42,46,47,52,54,59,61,69,78,85-87,89,94,95,98-100,109,115,126]$. 
Author Contributions: Conceptualization: M.W., E.M., H.M., S.T., H.C.K., J.S. (Jacob Speybroeck), M.M., C.M.B.; Methodology: M.W., E.M., H.M., H.C.K., J.S. (Jacob Speybroeck); Formal analysis: M.W., J.S. (John Stillson), A.V.T., A.G., J.A., D.F., S.V.L., L.S., Q.K.T.; Investigation: M.W., J.S. (John Stillson), A.V.T., A.G., J.A., D.F., S.V.L., L.S., Q.K.T.; Data curation: C.M.B., J.S. (John Stillson), A.V.T., A.G., J.A., D.F., S.V.L., L.S., Q.K.T.; Writing—original draft preparation: M.W., E.M., H.M., H.C.K., J.S. (Jacob Speybroeck), S.L., Q.K.T.; Writing-review and editing: M.W., E.M., H.M., S.T., H.C.K., J.S. (Jacob Speybroeck), M.M., C.M.B., J.S. (John Stillson), A.V.T., A.G., J.A., D.F., S.V.L., L.S., Q.K.T.; Supervision: M.W., S.L., Q.K.T., E.M., H.M.; All authors have read and agreed to the published version of the manuscript.

Funding: This research received no external funding.

Data Availability Statement: This study did not report any data.

Conflicts of Interest: Ernest Moore, Hunter Moore, Scott Thomas, and Hau Kwaan have received research grants from Haemonetics Corporation (Braintree, Massachusetts, USA).

\section{Abbreviations}

$\begin{array}{ll}\text { AABB } & \text { American Association of Blood Banks } \\ \text { BCT } & \text { blood component therapy } \\ \text { CFC } & \text { coagulation factor concentrates } \\ \text { CSWB } & \text { cold-stored whole blood } \\ \text { E-FIT1 } & \text { Early-Fibrinogen In Trauma 1 } \\ \text { FEISTY } & \text { Fibrinogen Early In Severe Trauma study } \\ \text { FiiRST } & \text { Fibrinogen in the initial Resuscitation of Severe Trauma } \\ \text { FinTIC } & \text { European prehospital Fibrinogen in Trauma-Induced Coagulopathy } \\ \text { GD BCT } & \text { goal-directed blood component therapy } \\ \text { ISS } & \text { injury severity score } \\ \text { iTACTIC } & \text { Treatment Algorithms for the Correction of Trauma-Induced Coagulopathy } \\ \text { LTLR } & \text { low-titer, leukocyte-reduced } \\ \text { LTOWB } & \text { low-titer group O whole blood } \\ \text { MT } & \text { massive transfusion } \\ \text { MTP } & \text { massive transfusion protocol } \\ \text { PCC } & \text { prothrombin complex concentrate } \\ \text { PLT } & \text { platelet } \\ \text { PPH } & \text { potentially preventable hemorrhage } \\ \text { PPOWER } & \text { Pragmatic, Prehospital, Type O, Whole Blood Early Resuscitation } \\ \text { PRBC } & \text { packed red blood cells } \\ \text { PROPPR } & \text { Pragmatic, Randomized Optimal Platelet and Plasma Ratios } \\ \text { RCT } & \text { Randomized control trial } \\ \text { RETIC } & \text { Reversal of Trauma-Induced Coagulopathy } \\ \text { ROTEM } & \text { rotational thromboelastometry } \\ \text { STORHM } & \text { Sang Total pour la Reanimation des Hemorragies Massives } \\ \text { SWAT } & \text { Shock, Whole Blood, and Assessment of TBI } \\ \text { TBI } & \text { traumatic brain injury } \\ \text { TEG } & \text { thromboelastography } \\ \text { THOR } & \text { Trauma Hemostasis and Oxygenation Research } \\ \text { TIC } & \text { trauma-induced coagulopathy } \\ \text { VET } & \text { viscoelastic test } \\ \text { WB } & \text { whole blood } \\ \text { WFWB } & \text { warm fresh whole blood } \\ & \end{array}$

\section{References}

1. Stubbs:, J.R.; Zielinski, M.D.; Jenkins, D. The state of the science of whole blood: Lessons learned at Mayo Clinic. Transfusion 2016, 56 (Suppl. 2), S173-S181. [CrossRef] [PubMed]

2. Zielinski, M.D.; Stubbs, J.R.; Berns, K.S.; Glassberg, E.; Murdock, A.D.; Shinar, E.; Sunde, G.A.; Williams, S.; Yazer, M.H.; Zietlow, S.; et al. Prehospital blood transfusion programs: Capabilities and lessons learned. J. Trauma Acute Care Surg. 2017, 82, S70-S78. [CrossRef] [PubMed] 
3. Cap, A.P.; Beckett, A.; Benov, A.; Borgman, M.; Chen, J.; Corley, J.B.; Doughty, H.; Fisher, A.; Glassberg, E.; Gonzales, R.; et al. Whole Blood Transfusion. Mil. Med. 2018, 183 (Suppl. 2), 44-51. [CrossRef] [PubMed]

4. Holcomb, J.B.; Jenkins, D.H. Get ready: Whole blood is back and it's good for patients. Transfusion 2018, 58, 1821. [CrossRef] [PubMed]

5. Pivalizza, E.G.; Stephens, C.T.; Sridhar, S.; Gumbert, S.D.; Rossmann, S.; Bertholf, M.F.; Bai, Y.; Cotton, B.A. Whole Blood for Resuscitation in Adult Civilian Trauma in 2017: A Narrative Review. Anesth. Analg. 2018, 127, 157-162. [CrossRef] [PubMed]

6. Yazer, M.H.; Cap, A.P.; Spinella, P.C.; Alarcon, L.; Triulzi, D.J. How do I implement a whole blood program for massively bleeding patients? Transfusion 2018, 58, 622-628. [CrossRef] [PubMed]

7. Jenkins, D.; Stubbs, J.; Williams, S.; Berns, K.; Zielinski, M.; Strandenes, G.; Zietlow, S. Implementation and execution of civilian remote damage control resuscitation programs. Shock 2014, 41, 84-89. [CrossRef]

8. Jenkins, D.H.; Rappold, J.F.; Badloe, J.F.; Berseus, O.; Blackbourne, L.; Brohi, K.H.; Butler, F.K.; Cap, A.P.; Cohen, M.J.; Davenport, R. Trauma hemostasis and oxygenation research position paper on remote damage control resuscitation: Definitions, current practice, and knowledge gaps. Shock 2014, 41, 3-12. [CrossRef]

9. Sperry, J.L.; Early, B.; Buck, M.; Silfies, L. Shock, Whole blood and Assessment of TBI (SWAT); University of Pittsburgh: Pittsburgh, PA, USA, 2018.

10. Yazer, M.H.; Seheult, J.; Kleinman, S.; Sloan, S.R.; Spinella, P.C. Who's afraid of incompatible plasma? A balanced approach to the safe transfusion of blood products containing ABO-incompatible plasma. Transfusion 2018, 58, 532-538. [CrossRef]

11. Holcomb, J.B.; Tilley, B.C.; Baraniuk, S.; Fox, E.E.; Wade, C.E.; Podbielski, J.M.; del Junco, D.J.; Brasel, K.J.; Bulger, E.M.; Callcut, R.A. Transfusion of plasma, platelets, and red blood cells in a 1:1:1 vs a 1:1:2 ratio and mortality in patients with severe trauma: The PROPPR randomized clinical trial. JAMA 2015, 313, 471-482. [CrossRef]

12. Dzik, W. Misunderstanding the PROPPR trial. Transfusion 2017, 57, 2056. [CrossRef] [PubMed]

13. Holcomb, J.B.; Donathan, D.P.; Cotton, B.A.; Del Junco, D.J.; Brown, G.; Wenckstern, T.V.; Podbielski, J.M.; Camp, E.A.; Hobbs, R.; Bai, Y. Prehospital Transfusion of Plasma and Red Blood Cells in Trauma Patients. Prehosp. Emerg. Care 2015, 19, 1-9. [CrossRef] [PubMed]

14. Holcomb, J.B.; Hess, J.R.; Group, P.S. Response to: “Misunderstanding the PROPPR trial". Transfusion 2017, 57, 2057-2058 [CrossRef] [PubMed]

15. Rijnhout, T.W.H.; Wever, K.E.; Marinus, R.; Hoogerwerf, N.; Geeraedts, L.M.G., Jr.; Tan, E.C. Is prehospital blood transfusion effective and safe in haemorrhagic trauma patients? A systematic review and meta-analysis. Injury 2019, 50, 1017-1027. [CrossRef] [PubMed]

16. Thies, K.-C.; Truhlář, A.; Keene, D.; Hinkelbein, J.; Rützler, K.; Brazzi, L.; Vivien, B. Pre-hospital blood transfusion-a survey on European practice. Scand. J. Trauma Resusc. Emerg. Med. 2020, 28, 1-8. [CrossRef] [PubMed]

17. Vanderspurt, C.K.; Spinella, P.C.; Cap, A.P.; Hill, R.; Matthews, S.A.; Corley, J.B.; Gurney, J.M. The use of whole blood in US military operations in Iraq, Syria, and Afghanistan since the introduction of low-titer Type O whole blood: Feasibility, acceptability, challenges. Transfusion 2019, 59, 965-970. [CrossRef]

18. Seheult, J.N.; Bahr, M.P.; Spinella, P.C.; Triulzi, D.J.; Yazer, M.H. The Dead Sea needs salt water ... massively bleeding patients need whole blood: The evolution of blood product resuscitation. Transfus. Clin. Biol. 2019, 26, 174-179. [CrossRef]

19. Zhu, C.S.; Pokorny, D.M.; Eastridge, B.J.; Nicholson, S.E.; Epley, E.; Forcum, J.; Long, T.; Miramontes, D.; Schaefer, R.; Shiels, M. Give the trauma patient what they bleed, when and where they need it: Establishing a comprehensive regional system of resuscitation based on patient need utilizing cold-stored, low-titer O+ whole blood. Transfusion 2019, 59, 1429-1438. [CrossRef]

20. Leeper, C.M.; Yazer, M.H.; Cladis, F.P.; Saladino, R.; Triulzi, D.J.; Gaines, B.A. Use of Uncrossmatched Cold-Stored Whole Blood in Injured Children With Hemorrhagic Shock. JAMA Pediatrics 2018, 172, 491-492. [CrossRef]

21. McGinity, A.C.; Zhu, C.S.; Greebon, L.; Xenakis, E.; Waltman, E.; Epley, E.; Cobb, D.; Jonas, R.; Nicholson, S.E.; Eastridge, B.J. Prehospital low-titer cold-stored whole blood: Philosophy for ubiquitous utilization of O-positive product for emergency use in hemorrhage due to injury. J. Trauma Acute Care Surg. 2018, 84, S115-S119. [CrossRef]

22. Seheult, J.N.; Anto, V.; Alarcon, L.H.; Sperry, J.L.; Triulzi, D.J.; Yazer, M.H. Clinical outcomes among low-titer group O whole blood recipients compared to recipients of conventional components in civilian trauma resuscitation. Transfusion 2018, 58, 1838-1845. [CrossRef] [PubMed]

23. Strandenes, G.; Berseus, O.; Cap, A.P.; Hervig, T.; Reade, M.; Prat, N.; Sailliol, A.; Gonzales, R.; Simon, C.D.; Ness, P.; et al. Low titer group $\mathrm{O}$ whole blood in emergency situations. Shock 2014, 41, 70-75. [CrossRef] [PubMed]

24. Spinella, P.C. Warm fresh whole blood transfusion for severe hemorrhage: U.S. military and potential civilian applications. Crit. Care Med. 2008, 36, S340-345. [CrossRef] [PubMed]

25. Seheult, J.N.; Triulzi, D.J.; Alarcon, L.H.; Sperry, J.L.; Murdock, A.; Yazer, M.H. Measurement of haemolysis markers following transfusion of uncrossmatched, low-titre, group $\mathrm{O}+$ whole blood in civilian trauma patients: Initial experience at a level 1 trauma centre. Transfus. Med. 2017, 27, 30-35. [CrossRef]

26. Spinella, P.C. Zero preventable deaths after traumatic injury: An achievable goal. J. Trauma Acute Care Surg. 2017, 82, S2-S8. [CrossRef]

27. Condron, M.; Scanlan, M.; Schreiber, M. Massive transfusion of low-titer cold-stored O-positive whole blood in a civilian trauma setting. Transfusion 2019, 59, 927-930. [CrossRef] 
28. Cotton, B.A.; Podbielski, J.; Camp, E.; Welch, T.; del Junco, D.; Bai, Y.; Hobbs, R.; Scroggins, J.; Hartwell, B.; Kozar, R.A. A randomized controlled pilot trial of modified whole blood versus component therapy in severely injured patients requiring large volume transfusions. Ann. Surg. 2013, 258, 527-532; discussion 532-523. [CrossRef]

29. Gallaher, J.R.; Dixon, A.; Cockcroft, A.; Grey, M.; Dewey, E.; Goodman, A.; Schreiber, M. Large volume transfusion with whole blood is safe compared with component therapy. J. Trauma Acute Care Surg. 2020, 89, 238-245. [CrossRef]

30. Hazelton, J.P.; Cannon, J.W.; Zatorski, C.; Roman, J.S.; Moore, S.A.; Young, A.J.; Subramanian, M.; Guzman, J.F.; Fogt, F.; Moran, A.; et al. Cold-stored whole blood: A better method of trauma resuscitation? J. Trauma Acute Care Surg. 2019, 87, 1035-1041. [CrossRef]

31. Ho, K.M.; Leonard, A.D. Lack of effect of unrefrigerated young whole blood transfusion on patient outcomes after massive transfusion in a civilian setting. Transfusion 2011, 51, 1669-1675. [CrossRef]

32. Spinella, P.C.; Pidcoke, H.F.; Strandenes, G.; Hervig, T.; Fisher, A.; Jenkins, D.; Yazer, M.; Stubbs, J.; Murdock, A.; Sailliol, A. Whole blood for hemostatic resuscitation of major bleeding. Transfusion 2016, 56, S190-202. [CrossRef] [PubMed]

33. Williams, J.; Merutka, N.; Meyer, D.; Bai, Y.; Prater, S.; Cabrera, R.; Holcomb, J.B.; Wade, C.E.; Love, J.D.; Cotton, B.A. Safety profile and impact of low-titer group $\mathrm{O}$ whole blood for emergency use in trauma. J. Trauma Acute Care Surg. 2020, 88, 87-93. [CrossRef] [PubMed]

34. Yazer, M.H.; Spinella, P.C. Review of low titre group O whole blood use for massively bleeding patients around the world in 2019. ISBT Sci. Ser. 2019, 14, 276-281. [CrossRef]

35. Fadeyi, E.A.; Saha, A.K.; Naal, T.; Martin, H.; Fenu, E.; Simmons, J.H.; Jones, M.R.; Pomper, G.J. A comparison between leukocyte reduced low titer whole blood vs non-leukocyte reduced low titer whole blood for massive transfusion activation. Transfusion 2020. [CrossRef] [PubMed]

36. Hanna, K.; Bible, L.; Chehab, M.; Asmar, S.; Douglas, M.; Ditillo, M.; Castanon, L.; Tang, A.; Joseph, B. Nationwide analysis of whole blood hemostatic resuscitation in civilian trauma. J. Trauma Acute Care Surg. 2020, 89, 329-335. [CrossRef]

37. Shea, S.M.; Staudt, A.M.; Thomas, K.A.; Schuerer, D.; Mielke, J.E.; Folkerts, D.; Lowder, E.; Martin, C.; Bochicchio, G.V.; Spinella, P.C. The use of low-titer group $\mathrm{O}$ whole blood is independently associated with improved survival compared to component therapy in adults with severe traumatic hemorrhage. Transfusion 2020, 60, S2-S9. [CrossRef]

38. Leeper, C.M.; Yazer, M.H.; Triulzi, D.J.; Neal, M.D.; Gaines, B.A. Whole Blood is Superior to Component Transfusion for Injured Children: A Propensity Matched Analysis. Ann. Surg. 2020, 272, 590-594. [CrossRef]

39. Armand, R.; Hess, J.R. Treating coagulopathy in trauma patients. Transfus. Med. Rev. 2003, 17, 223-231. [CrossRef]

40. Moore, E.E.; Moore, H.B.; Chapman, M.P.; Gonzalez, E.; Sauaia, A. Goal-directed hemostatic resuscitation for trauma induced coagulopathy: Maintaining homeostasis. J. Trauma Acute Care Surg. 2018, 84 (Suppl. 1), S35-S40. [CrossRef]

41. Chang, R.; Eastridge, B.J.; Holcomb, J.B. Remote Damage Control Resuscitation in Austere Environments. Wilderness Environ. Med. 2017, 28, S124-S134. [CrossRef]

42. Gonzalez, E.; Moore, E.E.; Moore, H.B.; Chapman, M.P.; Chin, T.L.; Ghasabyan, A.; Wohlauer, M.V.; Barnett, C.C.; Bensard, D.D.; Biffl, W.L.; et al. Goal-directed Hemostatic Resuscitation of Trauma-induced Coagulopathy: A Pragmatic Randomized Clinical Trial Comparing a Viscoelastic Assay to Conventional Coagulation Assays. Ann. Surg. 2016, 263, 1051-1059. [CrossRef] [PubMed]

43. Tapia, N.M.; Chang, A.; Norman, M.; Welsh, F.; Scott, B.; Wall, M.J., Jr.; Mattox, K.L.; Suliburk, J. TEG-guided resuscitation is superior to standardized MTP resuscitation in massively transfused penetrating trauma patients. J. Trauma Acute Care Surg. 2013, 74, 378-385. [CrossRef] [PubMed]

44. Howley, I.W.; Haut, E.R.; Jacobs, L.; Morrison, J.J.; Scalea, T.M. Is thromboelastography (TEG)-based resuscitation better than empirical 1:1 transfusion? Trauma Surg. Acute Care Open 2018, 3, e000140. [CrossRef] [PubMed]

45. Hoffman, M.; Monroe III, D.M. A cell-based model of hemostasis. Thrombosis and Haemostasis 2001, 85, 958-965. [PubMed]

46. Walsh, M.; Thomas, S.; Kwaan, H.; Aversa, J.; Anderson, S.; Sundararajan, R.; Zimmer, D.; Bunch, C.; Stillson, J.; Draxler, D.; et al. Modern methods for monitoring hemorrhagic resuscitation in the United States: Why the delay? J. Trauma Acute Care Surg. 2020, 89, 1018-1022. [CrossRef] [PubMed]

47. Schochl, H.; Maegele, M.; Voelckel, W. Fixed ratio versus goal-directed therapy in trauma. Curr. Opin. Anaesthesiol. 2016, 29, 234-244. [CrossRef] [PubMed]

48. Kornblith, L.Z.; Moore, H.B.; Cohen, M.J. Trauma-induced coagulopathy: The past, present, and future. J. Thromb. Haemost. 2019, 17, 852-862. [CrossRef]

49. Maegele, M.; Lefering, R.; Yucel, N.; Tjardes, T.; Rixen, D.; Paffrath, T.; Simanski, C.; Neugebauer, E.; Bouillon, B.; AG Polytrauma of the German Trauma Society (DGU). Early coagulopathy in multiple injury: An analysis from the German Trauma Registry on 8724 patients. Injury 2007, 38, 298-304. [CrossRef]

50. Brohi, K.; Singh, J.; Heron, M.; Coats, T. Acute traumatic coagulopathy. J. Trauma 2003, 54, 1127-1130. [CrossRef]

51. Chang, R.; Cardenas, J.C.; Wade, C.E.; Holcomb, J.B. Advances in the understanding of trauma-induced coagulopathy. Blood 2016, 128, 1043-1049. [CrossRef]

52. Cochrane, C.; Chinna, S.; Um, J.Y.; Dias, J.D.; Hartmann, J.; Bradley, J.; Brooks, A. Site-Of-Care Viscoelastic Assay in Major Trauma Improves Outcomes and Is Cost Neutral Compared with Standard Coagulation Tests. Diagnostics 2020, 10, 248652. [CrossRef] [PubMed]

53. Dobson, G.P.; Letson, H.L.; Sharma, R.; Sheppard, F.R.; Cap, A.P. Mechanisms of early trauma-induced coagulopathy: The clot thickens or not? J. Trauma Acute Care Surg. 2015, 79, 301-309. [CrossRef] [PubMed] 
54. Johansson, P.I.; Stensballe, J.; Oliveri, R.; Wade, C.E.; Ostrowski, S.R.; Holcomb, J.B. How I treat patients with massive hemorrhage. Blood 2014, 124, 3052-3058. [CrossRef] [PubMed]

55. Johansson, P.I.; Stissing, T.; Bochsen, L.; Ostrowski, S.R. Thrombelastography and tromboelastometry in assessing coagulopathy in trauma. Scand. J. Trauma Resusc. Emerg. Med. 2009, 17, 45. [CrossRef] [PubMed]

56. MacLeod, J.B.; Lynn, M.; McKenney, M.G.; Cohn, S.M.; Murtha, M. Early coagulopathy predicts mortality in trauma. J. Trauma Acute Care Surg. 2003, 55, 39-44. [CrossRef] [PubMed]

57. Kaufmann, C.R.; Dwyer, K.M.; Crews, J.D.; Dols, S.J.; Trask, A.L. Usefulness of thrombelastography in assessment of trauma patient coagulation. J. Trauma 1997, 42, 716-720; discussion 720-722. [CrossRef] [PubMed]

58. Collins, P.W.; Cannings-John, R.; Bruynseels, D.; Mallaiah, S.; Dick, J.; Elton, C.; Weeks, A.D.; Sanders, J.; Aawar, N.; Townson, J. Viscoelastometric-guided early fibrinogen concentrate replacement during postpartum haemorrhage: OBS2, a double-blind randomized controlled trial. BJA Br. J. Anaesth. 2017, 119, 411-421. [CrossRef]

59. Holcomb, J.B.; Minei, K.M.; Scerbo, M.L.; Radwan, Z.A.; Wade, C.E.; Kozar, R.A.; Gill, B.S.; Albarado, R.; McNutt, M.K.; Khan, S. Admission rapid thrombelastography can replace conventional coagulation tests in the emergency department: Experience with 1974 consecutive trauma patients. Ann. Surg. 2012, 256, 476-486. [CrossRef]

60. Hunt, B.J.; Lyons, G. Thromboelastography should be available in every labour ward. Int. J. Obstet. Anesth. 2005, 14, 324-325. [CrossRef]

61. Subramanian, M.; Kaplan, L.J.; Cannon, J.W. Thromboelastography-Guided Resuscitation of the Trauma Patient. JAMA Surg. 2019, 154, 1152-1153. [CrossRef]

62. Etchill, E.; Sperry, J.; Zuckerbraun, B.; Alarcon, L.; Brown, J.; Schuster, K.; Kaplan, L.; Piper, G.; Peitzman, A.; Neal, M.D. The confusion continues: Results from an American Association for the Surgery of Trauma survey on massive transfusion practices among United States trauma centers. Transfusion 2016, 56, 2478-2486. [CrossRef] [PubMed]

63. Gorlinger, K.; Fries, D.; Dirkmann, D.; Weber, C.F.; Hanke, A.A.; Schochl, H. Reduction of Fresh Frozen Plasma Requirements by Perioperative Point-of-Care Coagulation Management with Early Calculated Goal-Directed Therapy. Transfus. Med. Hemother. 2012, 39, 104-113. [CrossRef] [PubMed]

64. Walsh, M.; Thomas, S.; Moore, E.; Moore, H.; Piscoya, A.; Hake, D.; Son, M.; Pohlman, T.; Wegner, J.; Bryant, J.; et al. Tranexamic Acid for Trauma Resuscitation in the United States of America. Semin. Thromb. Hemost. 2017, 43, 213-223. [PubMed]

65. Spahn, D.R.; Bouillon, B.; Cerny, V.; Coats, T.J.; Duranteau, J.; Fernandez-Mondejar, E.; Filipescu, D.; Hunt, B.J.; Komadina, R.; Nardi, G. Management of bleeding and coagulopathy following major trauma: An updated European guideline. Crit. Care 2013, 17, R76. [CrossRef] [PubMed]

66. Hess, J.R.; Lindell, A.L.; Stansbury, L.G.; Dutton, R.P.; Scalea, T.M. The prevalence of abnormal results of conventional coagulation tests on admission to a trauma center. Transfusion 2009, 49, 34-39. [CrossRef]

67. Wells, D.; Hess, J.R.; Sabath, D.E. Thromboelastography in Trauma: A 1-Year Institutional Experience. Am. J. Clin. Pathol. 2019, 152, S1-S2. [CrossRef]

68. Hartmann, J.; Walsh, M.; Grisoli, A.; Thomas, A.V.; Shariff, F.; McCauley, R.; Lune, S.V.; Zackariya, N.; Patel, S.; Farrell, M.S. Diagnosis and Treatment of Trauma-Induced Coagulopathy by Viscoelastography. Semin. Thromb. Hemost. 2020, 46, 134-146. [CrossRef]

69. Curry, N.S.; Davenport, R.; Pavord, S.; Mallett, S.V.; Kitchen, D.; Klein, A.A.; Maybury, H.; Collins, P.W.; Laffan, M. The use of viscoelastic haemostatic assays in the management of major bleeding: A British Society for Haematology Guideline. Br. J. Haematol. 2018, 182, 789-806. [CrossRef]

70. Schenk, B.; Gorlinger, K.; Treml, B.; Tauber, H.; Fries, D.; Niederwanger, C.; Oswald, E.; Bachler, M. A comparison of the new $\operatorname{ROTEM}((\mathrm{R}))$ sigma with its predecessor, the ROTEMdelta. Anaesthesia 2019, 74, 348-356. [CrossRef]

71. Lloyd-Donald, P.; Churilov, L.; Zia, F.; Bellomo, R.; Hart, G.; McCall, P.; Mårtensson, J.; Glassford, N.; Weinberg, L. Assessment of agreement and interchangeability between the TEG5000 and TEG6S thromboelastography haemostasis analysers: A prospective validation study. BMC Anesthesiol. 2019, 19, 45. [CrossRef]

72. Gorlinger, K.; Perez-Ferrer, A.; Dirkmann, D.; Saner, F.; Maegele, M.; Calatayud, A.A.P.; Kim, T.Y. The role of evidence-based algorithms for rotational thromboelastometry-guided bleeding management. Korean J. Anesthesiol. 2019, 72, 297-322. [CrossRef] [PubMed]

73. Veigas, P.V.; Callum, J.; Rizoli, S.; Nascimento, B.; da Luz, L.T. A systematic review on the rotational thrombelastometry $(\operatorname{ROTEM}(\mathrm{R}))$ values for the diagnosis of coagulopathy, prediction and guidance of blood transfusion and prediction of mortality in trauma patients. Scand. J. Trauma Resusc. Emerg. Med. 2016, 24, 114. [CrossRef] [PubMed]

74. Wafaisade, A.; Lefering, R.; Maegele, M.; Lendemans, S.; Flohe, S.; Hussmann, B.; Defosse, J.M.; Probst, C.; Paffrath, T.; Bouillon, B.; et al. Coagulation management of bleeding trauma patients is changing in German trauma centers: An analysis from the trauma registry of the German Society for Trauma Surgery. J. Trauma Acute Care Surg. 2012, 72, 936-942. [CrossRef] [PubMed]

75. Johansson, P.I. Goal-directed hemostatic resuscitation for massively bleeding patients: The Copenhagen concept. Transfus. Apher. Sci. 2010, 43, 401-405. [CrossRef] [PubMed]

76. Nardi, G.; Agostini, V.; Rondinelli, B.; Russo, E.; Bastianini, B.; Bini, G.; Bulgarelli, S.; Cingolani, E.; Donato, A.; Gambale, G.; et al. Trauma-induced coagulopathy: Impact of the early coagulation support protocol on blood product consumption, mortality and costs. Crit. Care 2015, 19, 83. [CrossRef] [PubMed] 
77. Fenger-Eriksen, C.; Lindberg-Larsen, M.; Christensen, A.Q.; Ingerslev, J.; Sorensen, B. Fibrinogen concentrate substitution therapy in patients with massive haemorrhage and low plasma fibrinogen concentrations. Br. J. Anaesth. 2008, 101, 769-773. [CrossRef]

78. Innerhofer, P.; Westermann, I.; Tauber, H.; Breitkopf, R.; Fries, D.; Kastenberger, T.; El Attal, R.; Strasak, A.; Mittermayr, M. The exclusive use of coagulation factor concentrates enables reversal of coagulopathy and decreases transfusion rates in patients with major blunt trauma. Injury 2013, 44, 209-216. [CrossRef]

79. Lim, R., Jr.; Olcott IV, C.; Robinsion, A.; Blaisedale, F. Platelet response and coagulation changes following massive blood replacement. J. Trauma Acute Care Surg. 1973, 13, 577-582. [CrossRef]

80. Mann, K.G.; Brummel, K.; Butenas, S. What is all that thrombin for? J. Thromb. Haemost. 2003, 1, 1504-1514. [CrossRef]

81. Martini, W.Z.; Rodriguez, C.M.; Cap, A.P.; Dubick, M.A. Efficacy of resuscitation with fibrinogen concentrate and platelets in traumatic hemorrhage swine model. J. Trauma Acute Care Surg. 2020, 89, S137-S145.

82. Rahe-Meyer, N.; Solomon, C.; Hanke, A.; Schmidt, D.S.; Knoerzer, D.; Hochleitner, G.; Sorensen, B.; Hagl, C.; Pichlmaier, M. Effects of fibrinogen concentrate as first-line therapy during major aortic replacement surgery: A randomized, placebo-controlled trial. Anesthesiology 2013, 118, 40-50. [CrossRef] [PubMed]

83. Sadeghi, M.; Atefyekta, R.; Azimaraghi, O.; Marashi, S.M.; Aghajani, Y.; Ghadimi, F.; Spahn, D.R.; Movafegh, A. A randomized, double blind trial of prophylactic fibrinogen to reduce bleeding in cardiac surgery. Braz. J. Anesthesiol. 2014, 64, 253-257. [CrossRef] [PubMed]

84. Yamamoto, K.; Usui, A.; Takamatsu, J. Fibrinogen concentrate administration attributes to significant reductions of blood loss and transfusion requirements in thoracic aneurysm repair. J. Cardiothorac. Surg. 2014, 9, 90. [CrossRef] [PubMed]

85. Marsden, M.; Benger, J.; Brohi, K.; Curry, N.; Foley, C.; Green, L.; Lucas, J.; Rossetto, A.; Stanworth, S.; Thomas, H.; et al. Coagulopathy, cryoprecipitate and CRYOSTAT-2: Realising the potential of a nationwide trauma system for a national clinical trial. Br. J. Anaesth. 2019, 122, 164-169. [CrossRef]

86. Fries, D. The early use of fibrinogen, prothrombin complex concentrate, and recombinant-activated factor VIIa in massive bleeding. Transfusion 2013, 53, 91S-95S. [CrossRef]

87. Innerhofer, P.; Fries, D.; Mittermayr, M.; Innerhofer, N.; von Langen, D.; Hell, T.; Gruber, G.; Schmid, S.; Friesenecker, B.; Lorenz, I.H. Reversal of trauma-induced coagulopathy using first-line coagulation factor concentrates or fresh frozen plasma (RETIC): A single-centre, parallel-group, open-label, randomised trial. Lancet Haematol. 2017, 4, e258-e271. [CrossRef]

88. Mengoli, C.; Franchini, M.; Marano, G.; Pupella, S.; Vaglio, S.; Marietta, M.; Liumbruno, G.M. The use of fibrinogen concentrate for the management of trauma-related bleeding: A systematic review and meta-analysis. Blood Transfus. 2017, 15, 318-324.

89. Nascimento, B.; Callum, J.; Tien, H.; Peng, H.; Rizoli, S.; Karanicolas, P.; Alam, A.; Xiong, W.; Selby, R.; Garzon, A.M. Fibrinogen in the initial resuscitation of severe trauma (FiiRST): A randomized feasibility trial. Br. J. Anaesth. 2016, 117, 775-782. [CrossRef]

90. Schochl, H.; Nienaber, U.; Maegele, M.; Hochleitner, G.; Primavesi, F.; Steitz, B.; Arndt, C.; Hanke, A.; Voelckel, W.; Solomon, C. Transfusion in trauma: Thromboelastometry-guided coagulation factor concentrate-based therapy versus standard fresh frozen plasma-based therapy. Crit. Care 2011, 15, R83. [CrossRef]

91. Yamamoto, K.; Yamaguchi, A.; Sawano, M.; Matsuda, M.; Anan, M.; Inokuchi, K.; Sugiyama, S. Pre-emptive administration of fibrinogen concentrate contributes to improved prognosis in patients with severe trauma. Trauma Surg. Acute Care Open 2016, 1, e000037. [CrossRef]

92. Curry, N.; Foley, C.; Wong, H.; Mora, A.; Curnow, E.; Zarankaite, A.; Hodge, R.; Hopkins, V.; Deary, A.; Ray, J. Early fibrinogen concentrate therapy for major haemorrhage in trauma (E-FIT 1): Results from a UK multi-centre, randomised, double blind, placebo-controlled pilot trial. Crit. Care 2018, 22, 1-9. [CrossRef] [PubMed]

93. Maegele, M.; Zinser, M.; Schlimp, C.; Schochl, H.; Fries, D. Injectable hemostatic adjuncts in trauma: Fibrinogen and the FlinTIC study. J. Trauma Acute Care Surg. 2015, 78, S76-82. [CrossRef] [PubMed]

94. Spahn, D.R.; Bouillon, B.; Cerny, V.; Duranteau, J.; Filipescu, D.; Hunt, B.J.; Komadina, R.; Maegele, M.; Nardi, G.; Riddez, L. The European guideline on management of major bleeding and coagulopathy following trauma: Fifth edition. Crit. Care 2019, 23, 98. [CrossRef] [PubMed]

95. Ziegler, B.; Bachler, M.; Haberfellner, H.; Niederwanger, C.; Innerhofer, P.; Hell, T.; Kaufmann, M.; Maegele, M.; Martinowitz, U.; Nebl, C.; et al. Efficacy of prehospital administration of fibrinogen concentrate in trauma patients bleeding or presumed to bleed (FIinTIC): A multicentre, double-blind, placebo-controlled, randomised pilot study. Eur. J. Anaesthesiol. EJA 2019, 37, 1-10. [CrossRef] [PubMed]

96. Kaserer, A.; Casutt, M.; Sprengel, K.; Seifert, B.; Spahn, D.R.; Stein, P. Comparison of two different coagulation algorithms on the use of allogenic blood products and coagulation factors in severely injured trauma patients: A retrospective, multicentre, observational study. Scand. J. Trauma Resusc. Emerg. Med. 2018, 26, 4. [CrossRef]

97. Winearls, J.; Wullschleger, M.; Wake, E.; Hurn, C.; Furyk, J.; Ryan, G.; Trout, M.; Walsham, J.; Holley, A.; Cohen, J. Fibrinogen Early In Severe Trauma studY (FEISTY): Study protocol for a randomised controlled trial. Trials 2017, 18, 1-11. [CrossRef]

98. Chipman, A.M.; Jenne, C.; Wu, F.; Kozar, R.A. Contemporary resuscitation of hemorrhagic shock: What will the future hold? Am. J. Surg. 2020, 220, 580-588. [CrossRef]

99. Baksaas-Aasen, K.; Gall, L.S.; Stensballe, J.; Juffermans, N.P.; Curry, N.; Maegele, M.; Brooks, A.; Rourke, C.; Gillespie, S.; Murphy, J. Viscoelastic haemostatic assay augmented protocols for major trauma haemorrhage (ITACTIC): A randomized, controlled trial SSRN Electron. J. 2020, 47. [CrossRef] 
100. Stettler, G.R.; Moore, E.E.; Moore, H.B.; Nunns, G.R.; Silliman, C.C.; Banerjee, A.; Sauaia, A. Redefining postinjury fibrinolysis phenotypes using two viscoelastic assays. J. Trauma Acute Care Surg. 2019, 86, 679-685. [CrossRef]

101. Stettler, G.R.; Moore, E.E.; Nunns, G.R.; Chandler, J.; Peltz, E.; Silliman, C.C.; Banerjee, A.; Sauaia, A. Rotational thromboelastometry thresholds for patients at risk for massive transfusion. J. Surg. Res. 2018, 228, 154-159. [CrossRef]

102. Mitra, B.; Cameron, P.A.; Gruen, R.L.; Mori, A.; Fitzgerald, M.; Street, A. The definition of massive transfusion in trauma: A critical variable in examining evidence for resuscitation. Eur. J. Emerg. Med. 2011, 18, 137-142. [CrossRef] [PubMed]

103. Nunns, G.R.; Moore, E.E.; Chapman, M.P.; Moore, H.B.; Stettler, G.R.; Peltz, E.; Burlew, C.C.; Silliman, C.C.; Banerjee, A.; Sauaia, A. The hypercoagulability paradox of chronic kidney disease: The role of fibrinogen. Am. J. Surg. 2017, 214, 1215-1218. [CrossRef] [PubMed]

104. Kalkwarf, K.J.; Drake, S.A.; Yang, Y.; Thetford, C.; Myers, L.; Brock, M.; Wolf, D.A.; Persse, D.; Wade, C.E.; Holcomb, J.B. Bleeding to death in a big city: An analysis of all trauma deaths from hemorrhage in a metropolitan area during 1 year. J. Trauma Acute Care Surg. 2020, 89, 716-722. [PubMed]

105. Bieler, D.; Franke, A.F.; Hentsch, S.; Paffrath, T.; Willms, A.; Lefering, R.; Kollig, E.W.; TraumaRegister, D.G.U. Gunshot and stab wounds in Germany-Epidemiology and outcome: Analysis from the TraumaRegister DGU(R). Unfallchirurg 2014, 117, 995-1004. [CrossRef] [PubMed]

106. Dijkink, S.; Krijnen, P.; Hage, A.; Van der Wilden, G.M.; Kasotakis, G.; Hartog, D.D.; Salim, A.; Goslings, J.C.; Bloemers, F.W.; Rhemrev, S.J.; et al. Differences in Characteristics and Outcome of Patients with Penetrating Injuries in the USA and the Netherlands: A Multi-institutional Comparison. World J. Surg. 2018, 42, 3608-3615. [CrossRef]

107. Al-Shaqsi, S. Models of International Emergency Medical Service (EMS) Systems. Oman Med. J. 2010, 25, 320. [CrossRef]

108. Oakeshott, J.E.; Griggs, J.E.; Wareham, G.M.; Lyon, R.M. Feasibility of prehospital freeze-dried plasma administration in a UK Helicopter Emergency Medical Service. Eur J. Emerg. Med. 2019, 26, 373-378. [CrossRef]

109. Curry, N.S.; Davenport, R. Transfusion strategies for major haemorrhage in trauma. Br. J. Haematol. 2019, 184, 508-523. [CrossRef]

110. Rourke, C.; Curry, N.; Khan, S.; Taylor, R.; Raza, I.; Davenport, R.; Stanworth, S.; Brohi, K. Fibrinogen levels during trauma hemorrhage, response to replacement therapy, and association with patient outcomes. J. Thromb. Haemost. 2012, 10, $1342-1351$. [CrossRef]

111. Fries, D.; Krismer, A.; Klingler, A.; Streif, W.; Klima, G.; Wenzel, V.; Haas, T.; Innerhofer, P. Effect of fibrinogen on reversal of dilutional coagulopathy: A porcine model. Br. J. Anaesth. 2005, 95, 172-177. [CrossRef]

112. Gorlinger, K.; Dirkmann, D.; Hanke, A.A. Potential value of transfusion protocols in cardiac surgery. Curr. Opin. Anaesthesiol. 2013, 26, 230-243. [CrossRef] [PubMed]

113. Görlinger, K.; Dirkmann, D.; Hanke, A.A.; Kamler, M.; Kottenberg, E.; Thielmann, M.; Jakob, H.; Peters, J. First-Line Therapy With Coagulation Factor Concentrates Combined With Point-of-Care Coagulation Testing is Associated With Decreased Allogeneic Blood Transfusion in Cardiovascular Surgery. Surv. Anesthesiol. 2012, 56, 163-164. [CrossRef]

114. Lier, H.; Vorweg, M.; Hanke, A.; Gorlinger, K. Thromboelastometry guided therapy of severe bleeding. Essener Runde algorithm. Hamostaseologie 2013, 33, 51-61. [PubMed]

115. Schöchl, H.; Voelckel, W.; Schlimp, C. Management of traumatic haemorrhage-The European perspective. Anaesthesia 2015, 70, 102-107, e135-e137. [CrossRef] [PubMed]

116. Trzebicki, J.; Flakiewicz, E.; Kosieradzki, M.; Blaszczyk, B.; Kołacz, M.; Jureczko, L.; Pacholczyk, M.; Chmura, A.; Lagiewska, B.; Lisik, W. The use of thromboelastometry in the assessment of hemostasis during orthotopic liver transplantation reduces the demand for blood products. Ann. Transplant. 2010, 15, 19-24. [PubMed]

117. Wang, S.-C.; Shieh, J.-F.; Chang, K.-Y.; Chu, Y.-C.; Liu, C.-S.; Loong, C.-C.; Chan, K.-H.; Mandell, S.; Tsou, M.-Y. Thromboelastography-Guided Transfusion Decreases Intraoperative Blood Transfusion during Orthotopic Liver Transplantation: Randomized Clinical Trial. Transplant. Proc. 2010, 42, 2590-2593. [CrossRef] [PubMed]

118. Fenger-Eriksen, C.; Fries, D.; David, J.-S.; Bouzat, P.; Lance, M.D.; Grottke, O.; Spahn, D.R.; Schoechl, H.; Maegele, M. Pre-hospital plasma transfusion: A valuable coagulation support or an expensive fluid therapy? BioMed Central 2019, 23, 238. [CrossRef]

119. Gauss, T.; Lamblin, A.; Bouzat, P. The Twilight Zone: Ten beliefs about viscoelastic tests. Anaesth. Crit. Care Pain Med. 2019, 38 , 449-450. [CrossRef]

120. Schochl, H.; Nienaber, U.; Hofer, G.; Voelckel, W.; Jambor, C.; Scharbert, G.; Kozek-Langenecker, S.; Solomon, C. Goal-directed coagulation management of major trauma patients using thromboelastometry (ROTEM)-guided administration of fibrinogen concentrate and prothrombin complex concentrate. Crit. Care 2010, 14, R55. [CrossRef]

121. Bugaev, N.; Como, J.J.; Golani, G.; Freeman, J.J.; Sawhney, J.S.; Vatsaas, C.J.; Yorkgitis, B.K.; Kreiner, L.A.; Garcia, N.M.; Aziz, H.A.; et al. Thromboelastography and rotational thromboelastometry in bleeding patients with coagulopathy: Practice management guideline from the Eastern Association for the Surgery of Trauma. J. Trauma Acute Care Surg. 2020, 89, 999-1017. [CrossRef]

122. Espinosa, A.; Seghatchian, J. What is happening? The evolving role of the blood bank in the management of the bleeding patient: The impact of TEG as an early diagnostic predictor for bleeding. Transfus. Apher. Sci. 2014, 51, 105-110. [CrossRef] [PubMed]

123. Grottke, O.; Levy, J.H. Prothrombin complex concentrates in trauma and perioperative bleeding. J. Am. Soc. Anthesiol. 2015, 122, 923-931. [CrossRef] [PubMed]

124. Sperry, J. Pragmatic Prehospital Group O Whole Blood Early Resuscitation (PPOWER) Trial: A Prospective, Interventional, Randomized, 3 Year, Pilot Clinical Trial; National Heart, Lung, and Blood Institute (NHLBI): Bethesda, MD, USA, 2018. 
125. Ausset, S.; Pouget, T.; Begué, S.; Gross, S.; Martinaud, C.; Tiberghien, P. La prise en charge transfusionnelle de l’hémorragie massive: étude STORHM. Trans. Clin. Biol. 2019, 26, S24. [CrossRef]

126. Walsh, M.; Fries, D.; Moore, E.; Moore, H.; Thomas, S.; Kwaan, H.C.; Marsee, M.K.; Grisoli, A.; McCauley, R.; Lune, S.V. Whole blood for civilian urban trauma resuscitation: Historical, present, and future considerations. Semin. Thromb. Hemost. 2020, 46, 221-234. [CrossRef] [PubMed] 